\title{
Contasure-needleless single incision slings versus transobturator slings (TOT/TVT-O) for female patients with stress urinary incontinence: a systematic review and meta-analysis
}

Zhenkai Luo ${ }^{1,2 \dagger}$, Binbin Jiao ${ }^{2,3 \dagger}$, Hang Zhao ${ }^{1,2}$, Hailong Liu' ${ }^{1,2}$, Shicong Lai ${ }^{4,5}$ and Guan Zhang ${ }^{1,2,3^{*}}$ (D)

\begin{abstract}
Background: To assess the current evidence on the effectiveness and safety of Contasure-Needleless (C-NDL) versus transobturator slings (TOT/TVT-O) in the management of female stress urinary incontinence (SUI).
\end{abstract}

Methods: A comprehensive literature review of articles that investigated the efficacy and safety of C-NDL and TOT/ TVT-O was performed based on studies published before June 2019 and retrieved from PubMed, Embase, CNKI and the Cochrane Library. Two reviewers searched the literature, independently extracted the data and evaluated the quality of the data according to the inclusion and exclusion criteria. A meta-analysis was performed by using Review Manager 5.3 software.

Results: Seven studies with 1188 SUI female patients without intrinsic sphincter deficiency (ISD) or mixed urinary incontinence were included. Our meta-analysis showed that the clinical efficacy of C-NDL is statistically non-inferior to that of TOT / TVT-O in terms of subjective cure rate $[\mathrm{OR}=0.77,95 \%$ confidence interval (Cl) (0.53 to 1.10), $p=$ $0.15]$ and objective cure rate $[\mathrm{OR}=0.78,95 \% \mathrm{Cl}(0.53$ to 1.13$), p=0.19]$. In addition, operating times were statistically shorter with C-NDL compared to TOT / TVT-O [mean difference (MD) $=-7.38,95 \% \mathrm{Cl}(-10.73$ to -4.04$), p<$ 0.0001]. In terms of the postoperative visual analogue scale (VAS) and the incidence of postoperative pain, C-NDL has a greater advantage $[\mathrm{MD}=-1.71,95 \% \mathrm{Cl}(-2.91$ to -0.50$), p=0.005]$; $[\mathrm{OR}=0.21,95 \% \mathrm{Cl}(0.05$ to 0.96$), p=0.04]$. Complication rates were statistically similar between the groups, except for groin pain which was higher in TOT / TVT-O.

\footnotetext{
*Correspondence: gzhang2016@sina.com

${ }^{\dagger}$ Zhenkai Luo and Binbin Jiao contributed equally to this work.

${ }^{1}$ Peking University China-Japan Friendship School of Clinical Medicine, Beijing, China

${ }^{2}$ Department of Urology, China-Japan Friendship Hospital, Yinghuadong Road, Beijing 100029, Chaoyang District, China

Full list of author information is available at the end of the article
}

C C The Author(s). 2020 Open Access This article is licensed under a Creative Commons Attribution 4.0 International License, which permits use, sharing, adaptation, distribution and reproduction in any medium or format, as long as you give appropriate credit to the original author(s) and the source, provide a link to the Creative Commons licence, and indicate if changes were made. The images or other third party material in this article are included in the article's Creative Commons. licence, unless indicated otherwise in a credit line to the material. If material is not included in the article's Creative Commons licence and your intended use is not permitted by statutory regulation or exceeds the permitted use, you will need to obtain permission directly from the copyright holder. To view a copy of this licence, visit http://creativecommons.org/licenses/by/4.0/. The Creative Commons Public Domain Dedication waiver (http://creativecommons.org/publicdomain/zero/1.0/) applies to the data made available in this article, unless otherwise stated in a credit line to the data. 
(Continued from previous page)

Conclusion: Our data suggest that C-NDL slings have similar short-term efficacy as TOT/TVT-O in curing SUI patients. Compared with TOT/TVT-O, C-NDL is associated with a shorter operative time, and the incidence of postoperative pain is decreased. Nevertheless, these findings should be further confirmed through large-volume, well-designed prospective randomized controlled trials (RCTs) with long-term follow-up.

Keywords: Female stress urinary incontinence, Mini-slings, Needleless, Transobturator sling, Zhenkai Luo and Binbin Jiao are co-first authors.

\section{Background}

Stress urinary incontinence (SUI) is a common disease among middle-aged and elderly women. It is a widespread, global disease that affects $50 \%$ of women [1]. Symptoms of SUI are manifested as the involuntary flow of urine from the urethra when the patient coughs, sneezes or runs, all of which elevate abdominal pressure [2]. It is generally recognized that urethral closure pressure is the key factor maintaining continence [3]. When exertion raises the intra-abdominal pressure, an insufficient pressure of urethral closure will cause leakage. The lack of urethral closure pressure is associated with anatomic changes in the bladder and urethra $[4,5]$. Surgical treatment is now prioritized because of its efficacy when conservative therapy fails [6]. The purpose of surgical treatment is to reconstruct the anatomy and function through surgery and to restore normal urine control. However, for patients with intrinsic sphincter deficiency (ISD) or urgency urinary incontinence, a high failure rate of anti-incontinence surgeries has been reported [7, 8]. Surgical treatment of SUI has been developed for more than a century, and up to 200 surgical procedures are documented in the existing literature. The Burch retropubic urethropexy or MarshallMarchetti-Krantz (MMK) procedure through the retropubic routine was the gold-standard surgical treatment of SUI before the introduction of MUS [9]. Recently, the frequency of similar surgical approaches has decreased significantly. DeLancey proposed the hammock hypothesis in 1994 [10], which provided theoretical support for subsequent minimally invasive surgery, bringing revolutionary changes to surgery. Since the introduction of tension-free vaginal tape (TVT), similar surgical approaches have made great progress. At present, standard midurethral slings (SMUS) have become the first-line surgical treatment [6]. Among them, the transobturator sling (TOT/TVT-O) is widely used because of its high cure rate and lower number of complications [11-13]. However, persistent groin and thigh pain after surgery is the main complication affecting patient satisfaction [14].

Single incision mini-slings (SIMSs) were introduced in 2006 to make use of a shorter sling and a single vaginal incision [15]. The short- and medium-term efficacy of SIMS are still controversial due to its recent introduction. Currently, as a new category of SIMS, Contasure-Needleless (C-NDL) slings have a noninferior cure rate and fewer complications than transobturator slings $[16,17]$. To the best of our knowledge, there are no systematic reviews and metaanalyses of C-NDL slings. To better evaluate clinical efficacy and safety, we systematically assessed data about C-NDL and transobturator slings (TOT/TVT$\mathrm{O})$ to provide a reference for the surgical choice of SUI.

\section{Methods}

\section{Search strategy}

A comprehensive literature search was performed based on PubMed, Embase, CNKI and the Cochrane Library before June 2019. The following key words were used: "single-incision mini-sling", "Contasure-Needleless," "Needleless," "transobturator slings," "TVT-O," "TOT," and "stress urinary incontinence". We defined no language restrictions. Additionally, manual searches of the references and citation lists of all relevant reviews were performed. The literature selection was performed following the search strategy promoted by the Preferred Reporting Items for Systematic Reviews and Meta-analysis (PRISMA) guidelines.

\section{Inclusion and exclusion criteria}

The included studies met the following criteria: (1) the study type was randomized controlled trials (RCTs) or case-control trials (CCTs); (2) the study compared the efficacy and safety of C-NDL with TOT/TVT-O; (3) participants were females and diagnosed with SUI; (4) there was no statistically significant difference in the basic characteristics of the participants; and (5) the measurement outcomes included cure rate, surgery-related data, and postoperative complications.

Studies were excluded based on the following criteria: (1) no data were available for meta-analysis; (2) the study was not an original research study (i.e., it was a conference article, letter, comment, or review); (3) the followup time was too short, that is, less than 1 year; (4) the experimental group included other SIMSs; and. (5) patients were diagnosed with ISD or mixed urinary incontinence. 


\section{Data extraction and quality assessment}

The literature selection was completed according to the inclusion and exclusion criteria. Two reviewers (Z. L and B. J) independently extracted data and appraised both quality and content. The following items were extracted from each available study: first author, year of publication, country, study design, intervention, sample size, follow-up data, definition of subjective cure, definition of objective cure, relative outcome (including subjective cure rate, objective cure rate, operative time, hospitalization time, blood loss, visual analogue scale) and overall complications. All authors engaged in a discussion to resolve relative disagreements about eligibility and the senior reviewer (G. Z) made the final decision after discussion.

We evaluated the level of evidence (LE) for each selected article based on the criteria recommended by the Oxford-associated evidence-based medicine centre [18]. For methodological quality assessment, the Jadad scale [19] was used to assess the quality of RCTs. Studies with scores of 3-5 were defined as high-quality, and studies of scores of 0-2 were defined as low-quality. For CCTs, we used the Newcastle-Ottawa scale [20] to evaluate quality. We defined the studies with scores of 7-9 as high-quality, while those with scores of 0-6 were lowquality. The quality of the studies did not influence the decision to pool studies in the meta-analysis.

\section{Statistical analysis}

All meta-analyses were performed using Review Manager 5.3 software. The mean difference (MD) or standardized mean difference (SMD) was used to evaluate continuous outcomes. For studies that expressed continuous data as medians and range values, we chose the statistical formula demonstrated by Luo and Wan et al. $[21,22]$ to count the means and standard deviations. The results are expressed as the risk ratio (RR) or odds ratio (OR) with a 95\% confidence interval (CI) for dichotomous variables. The $\chi^{2}$ and I 2 tests (I2 > 50\% was regarded as substantial heterogeneity) were used to assess the heterogeneity of the study data. If heterogeneity was considered to be low, fixed-effects models were used for the meta-analyses. Otherwise, a random effects model was used to reduce the effect of statistical heterogeneity. The pooled effects were determined by the $\mathrm{z}$ test, and a $p$ value $<0.05$ was considered statistically significant. For several comparisons, sensitivity analyses were used. The results of the meta-analysis are expressed using forest graphs.

\section{Results}

Characteristics of the selected studies

After the searches and screens, seven articles [17, 2328 ] were ultimately included. The selection or exclusion of literature at each stage is presented in a flowchart (Fig. 1). A total of 603 cases of C-NDL and 585 cases of TOT/TVT-O were selected in this meta-analysis, including five RCTs and two CCTs. The baseline characteristics and quality assessment of the included studies are shown in a table (Table 1). According to the scoring criteria, these studies are defined as high-quality.

\section{Subjective and objective cure rate}

All 7 studies were included in the forest plot of the subjective cure rate. A fixed-effects model was applied due to the lack of heterogeneity among these trials $\left(\mathrm{I}^{2}=0 \%\right)$. The overall results for the subjective cure rate showed no significant difference between the two groups [OR = $0.77,95 \%$ CI (0.53 to 1.10$), p=0.15$ ] (Fig. 2a). For the analysis of the objective cure rate, 6 studies were included. No significant difference was found from the pooled analysis $[\mathrm{OR}=0.78,95 \% \mathrm{CI}$ (0.53 to 1.13$), p=$ 0.19] (Fig. 2b).

\section{Operation details Operative time}

Four studies measured the intraoperative duration of $\mathrm{C}$ NDL and TOT/TVT-O. We chose the random effects model due to the high heterogeneity $\left(\mathrm{I}^{2}=98 \%\right)$. The analysis results demonstrated that $\mathrm{C}$-NDL slings incurred a shorter operative time than TOT/TVT-O slings $[\mathrm{MD}=$ $-7.38,95 \%$ CI (-10.73 to -4.04$), p<0.0001$ ] (Fig. 3a).

\section{Blood loss}

Regarding blood loss, the data provided by three studies were analysed by a random effects model with high heterogeneity $\left(\mathrm{I}^{2}=89 \%\right)$. When pooled, the results showed that the $\mathrm{C}-\mathrm{NDL}$ group had significantly less bleeding $[\mathrm{MD}=-$ 8.01, 95\% CI ( -15.71 to -0.30$), p=0.04$ ] (Fig. 3b).

\section{Hospital stay}

Four studies reported data on hospitalization time. A random effects model was used due to the high heterogeneity $\left(\mathrm{I}^{2}=99 \%\right)$. No remarkable difference was found between the two groups $[\mathrm{MD}=-0.39,95 \% \mathrm{CI}(-1.34$ to 0.57), $p=0.43$ ] (Fig. 3c).

\section{Postoperative visual analogue scale}

For the visual analogue scale (VAS), a total of three studies met the inclusion criteria. Due to the high heterogeneity $\left(\mathrm{I}^{2}=95 \%\right)$, we used a random effects model. The combined result showed a significant difference between C-NDL and TOT/TVT-O [MD $=-1.71,95 \% \mathrm{CI}$ $(-2.91$ to -0.50$), p=0.005$ ] (Fig. 3d).

\section{Postoperative pain or discomfort}

A total of four studies met the inclusion criteria for this outcome. Due to the high heterogeneity $\left(\mathrm{I}^{2}=56 \%\right)$, a 


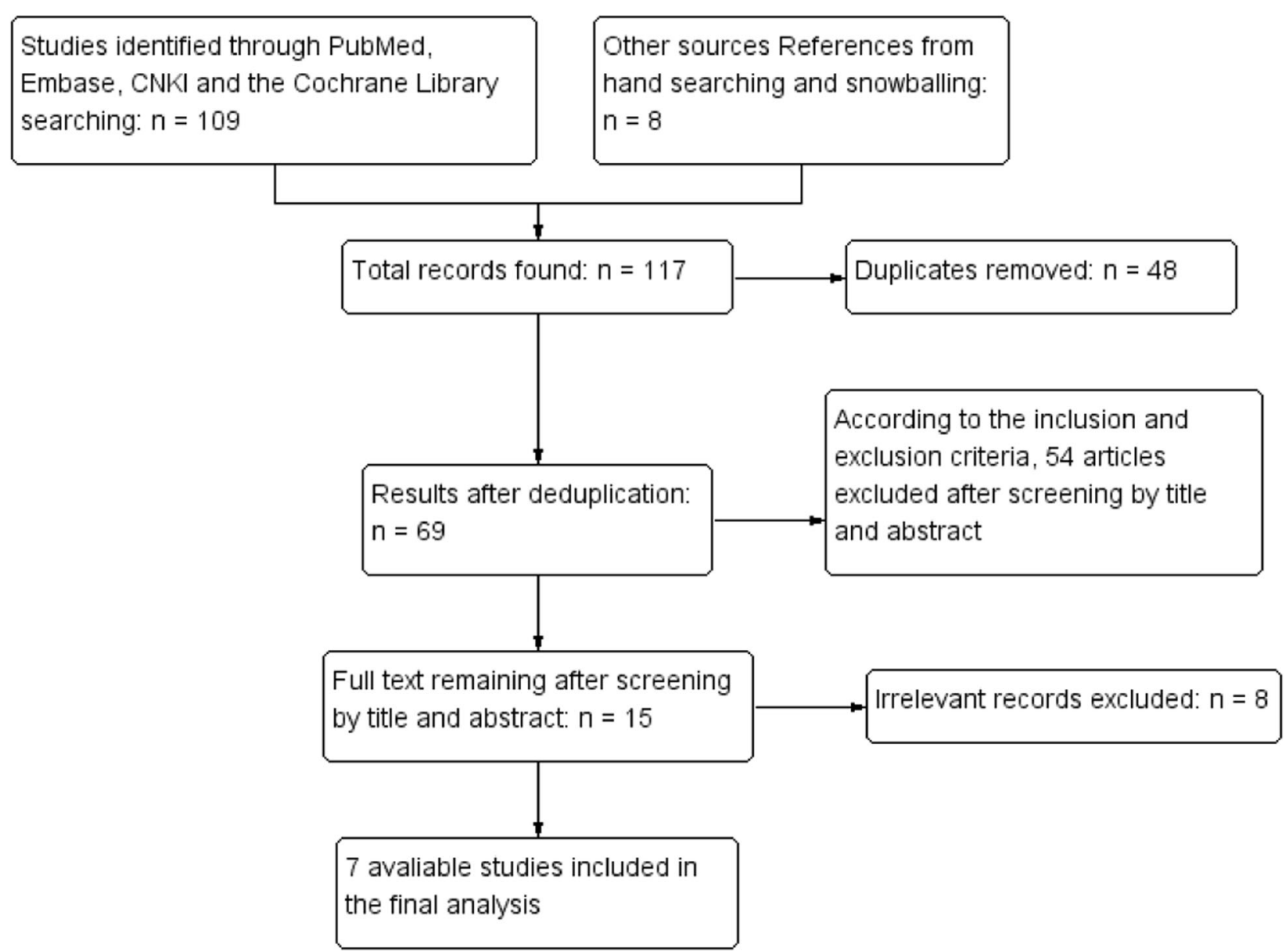

Fig. 1 PRISMA flowchart

random effects model was applied. The result was statistically significant in favour of C-NDL [OR $=0.21,95 \% \mathrm{CI}$ (0.05 to 0.96), $p=0.04$ ] (Fig. 3e).

\section{Adverse events}

Three trials were included in the statistical analysis to detect the incidence rate of postoperative groin pain. The outcome strongly supported that C-NDL slings have a lower incidence rate than TOT/TVT-O slings $[\mathrm{RR}=$ 0.11, 95\% CI (0.02 to 0.61), $p=0.01$ ] (Fig. 4a). There were no statistically significant differences between $\mathrm{C}$ NDL and TOT/TVT-O slings in the rate of urinary retention $[\mathrm{OR}=0.72,95 \% \mathrm{CI}(0.37$ to 1.41$), p=0.34$ ] (Fig. $4 \mathrm{~b})$, de novo urgency and/or worsening of pre-existing urgency $[\mathrm{OR}=0.68,95 \% \mathrm{CI}$ (0.42 to 1.09$), p=0.11]$ (Fig. $4 c)$, difficulty urinating $[\mathrm{OR}=0.64,95 \% \mathrm{CI} \quad(0.22$ to 1.82), $p=0.40$ ] (Fig. 4d), vaginal tape erosion $[\mathrm{OR}=0.75$, $95 \%$ CI (0.36 to 1.57$), p=0.44$ ] (Fig. 4e), urinary tract infection $[\mathrm{OR}=1.71,95 \% \mathrm{CI}(0.59$ to 4.93$), p=0.32]$ (Fig. $4 \mathrm{f})$, bladder injury [OR $=0.77,95 \% \mathrm{CI}(0.22$ to 2.70$), p=$ 0.69] (Fig. 4g), or haematoma [OR $=0.79,95 \%$ CI $(0.24$ to 2.62), $p=0.70$ ] (Fig. $4 \mathrm{~h}$ ).

\section{Publication bias}

To evaluate publication bias, a funnel plot (Fig. 5) was constructed. No obvious asymmetry was shown, revealing that no publication bias existed in our meta-analysis.

\section{Discussion}

With a grade A commendation according to the European Association of Urology (EAU) guidelines, SMUS is widely used to treat SUI [29]. The midurethral slings can be classified into 3 generations throughout their development history. As the first generation, TVT was introduced in 1995 [30] and became the best choice for the surgical treatment of SUI due to its minimal invasiveness and high cure rate. However, as a retropubic sling, the main complications include voiding dysfunction and bladder injuries, which decrease its safety [31, 32]. To avoid potential complications associated with retropubic placement, a mesh inserted through the obturator foramen was created. Delorme introduced the "outside-in" technique (TOT), placing the suburethral tape via a transobturator route in 2001 [33]. Subsequently, the "inside-out" technique (TVT-O) was modified by De Leval 
Table 1 Summary of comparative studies included in meta-analysis

\begin{tabular}{|c|c|c|c|c|c|c|c|c|c|c|c|c|}
\hline \multirow[t]{2}{*}{ Study } & \multirow[t]{2}{*}{ Country } & \multirow{2}{*}{$\begin{array}{l}\text { Study } \\
\text { period }\end{array}$} & \multirow{2}{*}{$\begin{array}{l}\text { Study } \\
\text { design }\end{array}$} & \multirow[t]{2}{*}{ LE } & \multicolumn{2}{|c|}{ Intervention } & \multicolumn{2}{|c|}{ Sample size } & \multirow{2}{*}{$\begin{array}{l}\text { Follow- } \\
\text { up }\end{array}$} & \multirow{2}{*}{$\begin{array}{l}\text { Study } \\
\text { quality }\end{array}$} & \multirow[t]{2}{*}{ Definition of subjective cure } & \multirow{2}{*}{$\begin{array}{l}\text { Definition of } \\
\text { objective cure }\end{array}$} \\
\hline & & & & & Trial & $\overline{\text { Control }}$ & Trial & Control & & & & \\
\hline $\begin{array}{l}\text { Dogan } \\
2018[23]\end{array}$ & Turkey & $\begin{array}{l}2014- \\
2016\end{array}$ & RCT & $2 a$ & $\begin{array}{l}\mathrm{C}- \\
\mathrm{NDL}\end{array}$ & TOT & 89 & 89 & $2 y$ & $4^{b}$ & $\begin{array}{l}\text { If the response to the (ICIQ-SF) question } \\
5 \text { "When does urine leak?" was "never/ } \\
\text { urine does not leak" }\end{array}$ & $\begin{array}{l}\text { Absence of } \\
\text { SUI and } \\
\text { negative CST }\end{array}$ \\
\hline $\begin{array}{l}\text { Fernandez } \\
2017[24]\end{array}$ & Spain & $\begin{array}{l}2010- \\
2014\end{array}$ & $\mathrm{RCT}$ & $2 a$ & $\begin{array}{l}C- \\
\text { NDL }\end{array}$ & TVT-O & 89 & 98 & $1 y$ & $4^{b}$ & $\begin{array}{l}\text { Very satisfied/satisfied in questionnaire } \\
\text { and postsurgical SSI is } 0\end{array}$ & Negative CST \\
\hline $\begin{array}{l}\text { Franco } \\
2014[17]\end{array}$ & Spain & $\begin{array}{l}2006- \\
2010\end{array}$ & $\mathrm{CCT}$ & $2 b$ & $\begin{array}{l}C- \\
\text { NDL }\end{array}$ & TVT-O & 131 & 108 & $5 y$ & $9^{\mathrm{a}}$ & $\begin{array}{l}\text { Very satisfied/satisfied in questionnaire } \\
\text { and postsurgical SSI is } 0\end{array}$ & Negative CST \\
\hline $\begin{array}{l}\text { Gaber } \\
2016[25]\end{array}$ & UK & $\begin{array}{l}2014- \\
2015\end{array}$ & RCT & $2 a$ & $\begin{array}{l}\mathrm{C}- \\
\mathrm{NDL}\end{array}$ & TVT-O & 70 & 70 & $1 y$ & $4^{\mathrm{b}}$ & $\begin{array}{l}\text { Very much improved/much improved on } \\
\text { PGI-I }\end{array}$ & $\begin{array}{l}\text { Negative CST } \\
\text { with full } \\
\text { bladder }\end{array}$ \\
\hline $\begin{array}{l}\text { LV } \\
\text { 2017[26] }\end{array}$ & China & $\begin{array}{l}2014- \\
2015\end{array}$ & $\mathrm{RCT}$ & $2 a$ & $\begin{array}{l}C- \\
\text { NDL }\end{array}$ & ТОТ & 78 & 86 & $1 y$ & $3^{b}$ & PGI-I & Not mention \\
\hline $\begin{array}{l}\text { Tardiu } \\
2011[27]\end{array}$ & Spain & $\begin{array}{l}2006- \\
2009\end{array}$ & $\mathrm{CCT}$ & $2 b$ & $\begin{array}{l}C- \\
\text { NDL }\end{array}$ & TVT-O & 72 & 60 & $1 y$ & $9^{a}$ & $\begin{array}{l}\text { Very satisfied/satisfied in questionnaire } \\
\text { and postsurgical SSI is } 0\end{array}$ & Negative CST \\
\hline $\begin{array}{l}\text { Xu } 2017 \\
{[28]}\end{array}$ & China & $\begin{array}{l}2014- \\
2016\end{array}$ & $\mathrm{RCT}$ & $2 a$ & $\begin{array}{l}\mathrm{C}- \\
\mathrm{NDL}\end{array}$ & TVT-O & 74 & 74 & $1 y$ & $3^{\mathrm{b}}$ & Postsurgical SSI is 0 & $\begin{array}{l}\text { Absence of } \\
\text { SUI and } \\
\text { negative CST }\end{array}$ \\
\hline
\end{tabular}

RCT Randomized controlled trial, CCT Case-control trials, LE Level of evidence, C-NDL Contasure-Needleless single incision slings, TVT-O Tension-free vaginal tapeobturator, TOT Transobturator tape

ICIQ-SF International Consultation on Incontinence Questionnaire -Short Form, SSI Sandvik Severity Index, PGI-I Patient global impression of improvement, CST Cough stress test

a Using Newcastle-Ottawa Scale (score from 0 to 9)

${ }^{\mathrm{b}}$ Using Jadad scale (score from 0 to 5 )

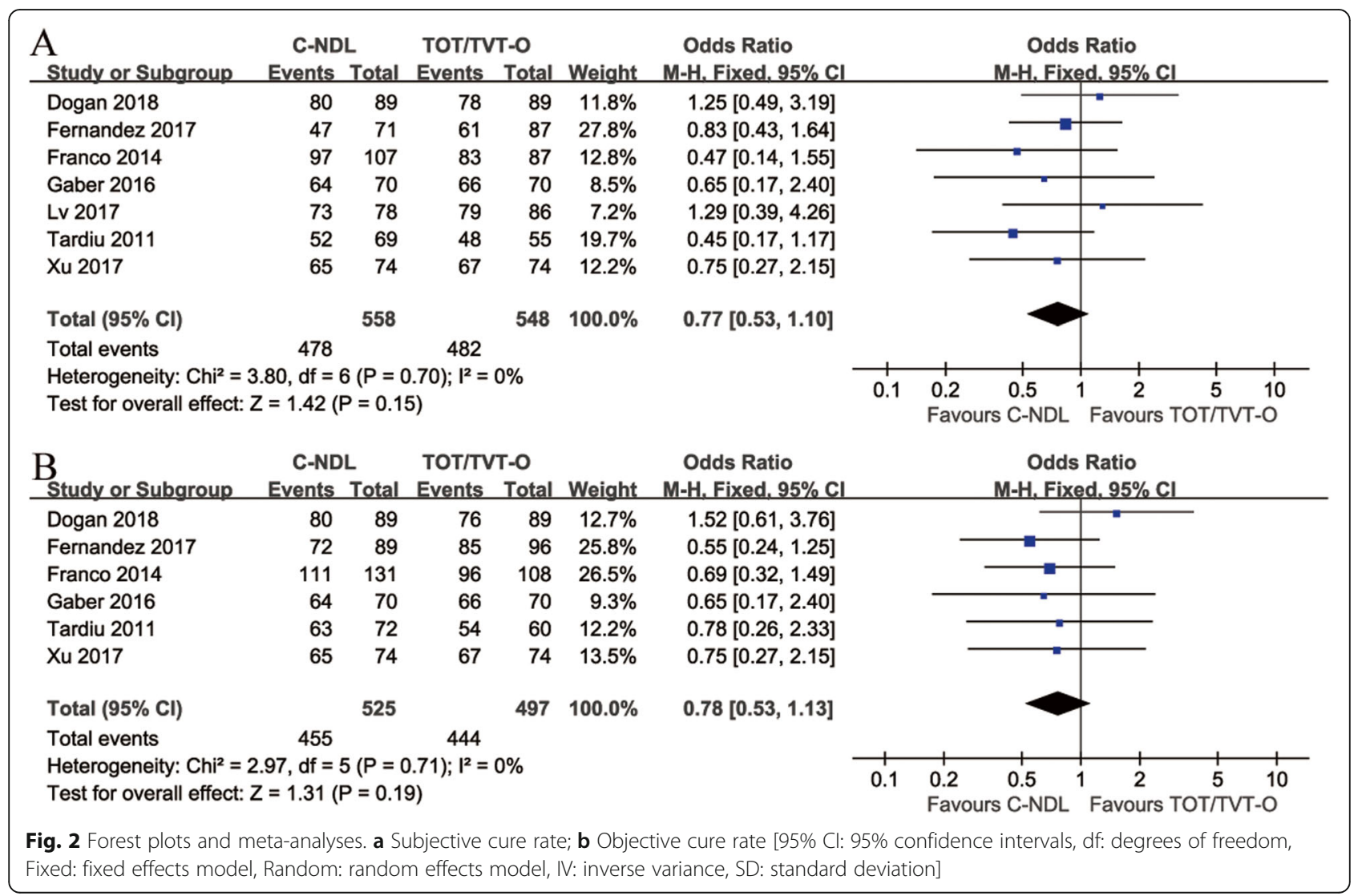




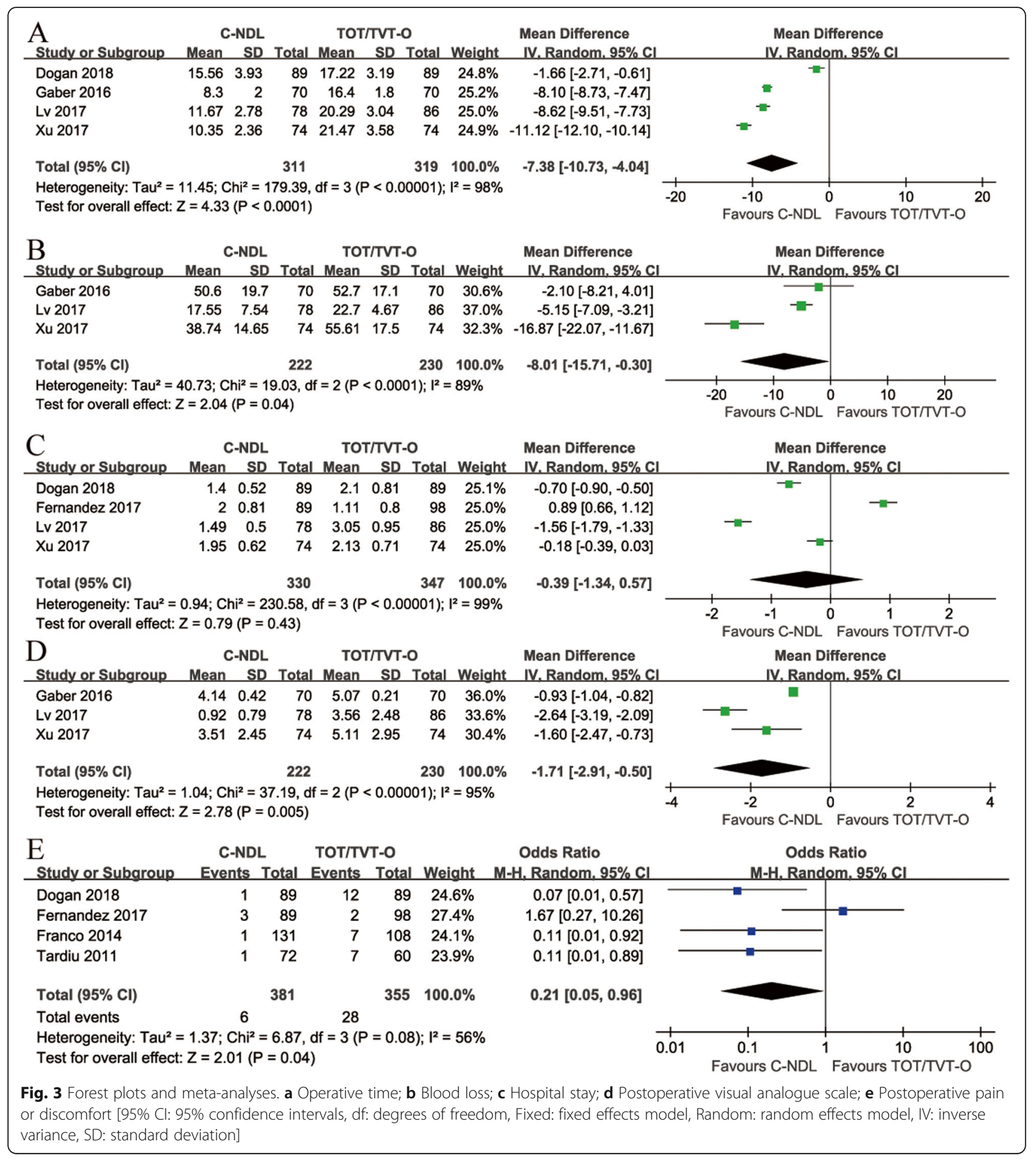

[34]. As the second generation, transobturator slings (TOT/TVT-O) achieve similar efficacy and fewer complications, especially regarding the risk of visceral injury [35]. Some studies mainly focused on primary SUI in females without ISD and mixed incontinence were performed to compare the efficacy of the two sling surgeries. The results from a five-year term showed that the subjective and objective cure rates were not significantly different between TVT and TVT-O, and there appeared to be very few complications during follow-up [12]. The meta-analysis performed by Huang et al. [36] showed that TOT can achieve a similar success rate as TVT and requires less operative time and a shorter hospital stay. Few studies reported outcomes with longer 


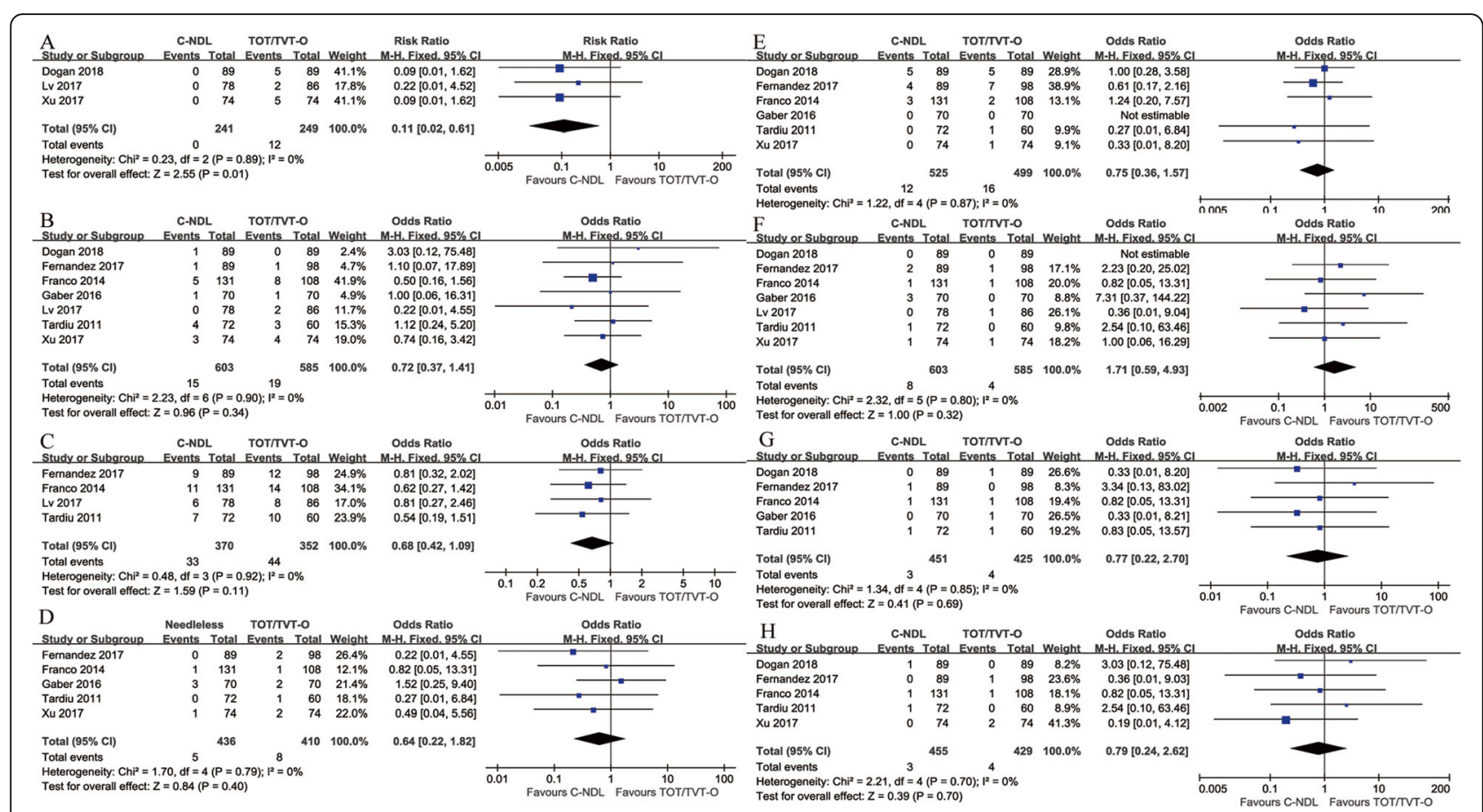

Fig. 4 Forest plots and meta-analyses. a Postoperative groin pain; b Urinary retention; c De novo urgency and/or worsening of pre-existing urgency; d Difficulty urinating; e Vaginal tape erosion; f Urinary tract infection; g Bladder injury; h Hematoma [95\% Cl: 95\% confidence intervals, df: degrees of freedom, Fixed: fixed effects model, Random: random effects model, IV: inverse variance, SD: standard deviation]

term follow-up for more than 5 years. According to the guide for stress urinary incontinence treatment, compared to transobturator slings, slings inserted by the retropubic routes have higher objective patient-reported cure rates at 8 years and lower re-operation rates [37]. In addition, when the tape is placed, the introducer needle passes through the obturator foramen blindly. The obturator nerve and blood vessel will likely be injured during the procedure, which may cause postoperative groin pain and haematoma. According to the existing literature focused on primary SUI in females, transient groin pain occurs in $0.8-7.5 \%$ of patients after the placement of transobturator slings $[38,39]$. It is worth mentioning that shorter than traditional transobturator slings, TVT-Abbrevo is only $12 \mathrm{~cm}$ long, achieves similar efficacy and reduces post-operative groin pain [40, 41].

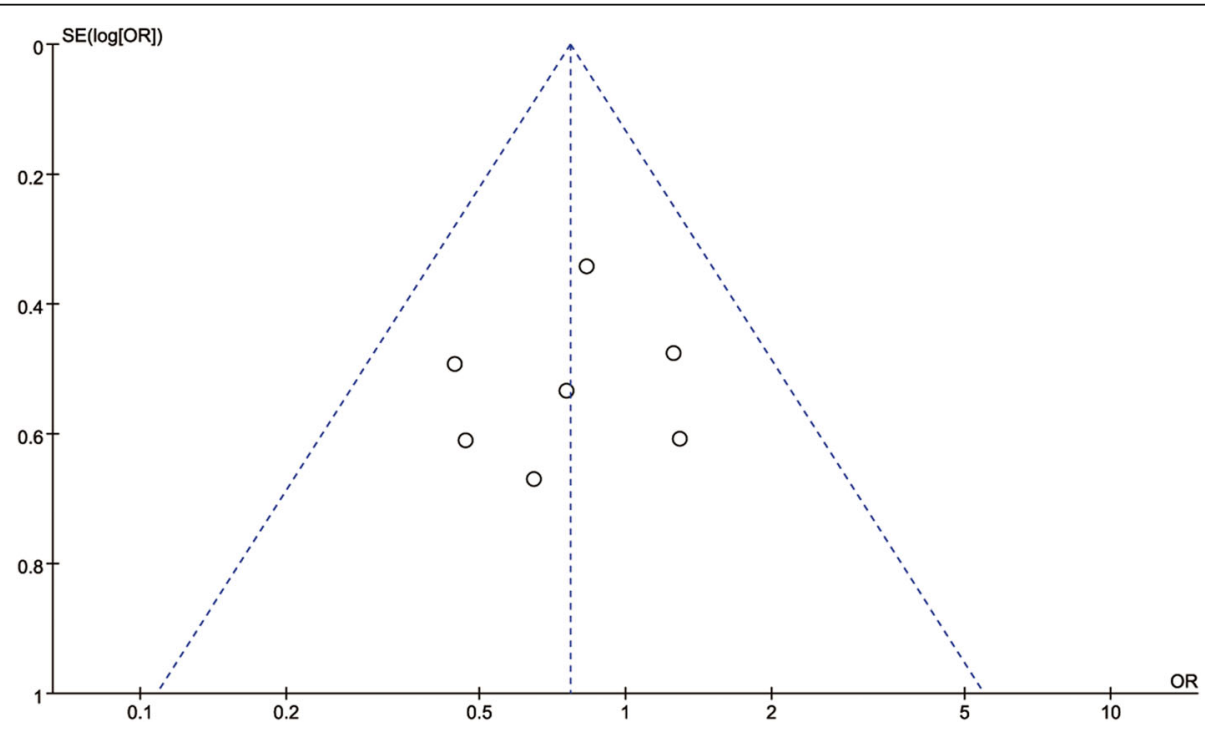

Fig. 5 Funnel plot of subjective cure rate for publication bias 
However, further long-term data and prospective studies are required to clarify its efficacy and safety. To simplify the surgical procedure and decrease the relative complication rate, the third-generation SIMS was introduced. With a shorter mesh and insertion into a single incision, SIMS provides a shorter operative time and fewer adverse effects, particularly regarding postoperative groin pain, vessel and bladder injury [1]. In contrast to other SIMSs, C-NDL has a unique shape. It is made of a polypropylene monofilament mesh with no guide needle and is apparently widened at both ends, which is called the T-pocket. This device aids surrounding tissue ingrowth to provide sufficient support for the urethra [42]. Surgical forceps are placed inside the T-pocket to fold the mesh by opening and closing the forceps. The forceps with the folded mesh are introduced into the paraurethral space and penetrate the internal obturator muscle by controlling the pushing force. The forceps are then opened to extend the T-pocket pocket inside the internal obturator muscles for fixation, closed, and pulled out of the vagina. The same manoeuvre is performed on the contralateral side to complete the sling insertion without twisting the tape. The surgeon can decrease the support by pulling on the two sutures in the middle of the mesh, leaving a space between the mesh and the urethra and allowing a surgical forceps to be interposed between them, thus avoiding any tension on the mesh $[24,25]$.

The most important indicators for evaluating efficacy are the subjective and objective cure rates. The tension provided by the tape support plays a significant role in efficacy and is associated with the cure rate and necessity for re-surgery. Some studies of SIMS have been performed previously to evaluate the efficacy. One metaanalysis compared the TVT-Secure, Mini-Arc and Ophira together with standard midurethral slings, and the result showed an inferior cure rate for these SIMSs [15]. An animal trial reported that with the highest surface area to counteract extraction, the anchor of the CNDL has the highest mean immediate extraction forces compared with other SIMSs [43]. Additionally, the surface area in the pelvic floor is almost the same as for the TVT-O, which ensures sufficient firmness [17]. Our meta-analysis, found no significant differences in the comparison of subjective and objective cure rates. However, Fernandez et al. (2017) reported that C-NDL was inferior in a comparison of negative stress test results and patient satisfaction [24]. In contrast to other included studies, they used a non-inferiority test for analysis. However, differences in the statistical tools used could have resulted in bias. In addition, there are no standardized assessment tools to evaluate the success rate. Patients may have different expectations regarding treatment after surgery for SUI, and some postoperative complications may also affect the subjective cure rate. Notably, four studies [17, 24, 25, 27] included patients with pelvic organ prolapse (POP). Because of the pelvic structure, SUI and POP are often comorbid diseases. For these patients, anti-incontinence surgery simultaneous with POP repair was undertaken. There is strong evidence that prolapse surgery combined with incontinence surgery reduces the risk of postoperative SUI [44]. Therefore, it is doubtless that many factors influence the cure rate. Regarding these aspects, more strict inclusion and exclusion criteria and standardized assessment tools are recommended to make the results more comparable. Apart from the investigations of Dogan in 2018 [23] and Franco in 2014 [17], the follow-up time of the included studies was only 1 year. Due to the limitations in followup time, only one study [23] (Dogan 2018) with a 2 year follow-up reported the incidence of repeated SUI surgery and revealed no significant differences between groups [C-NDL (1/89): TOT (0/89) $p>0.05]$. However, longer follow-up is required to determine re-operation rates. Our outcome can only indicate that C-NDL slings have similar short-term efficacy to transobturator slings. Due to the short period of C-NDL use, determination of long-term efficacy will require high quality-RCTs.

Our meta-analysis showed that the patients who underwent C-NDL had a shorter operative time (by 7 $\mathrm{min})$, confirming previously published outcomes $[1,45]$. Due to its unique T-pocket, the mesh implant is simpler and more convenient. However, this shorter operative time may not contribute to improving the safety of the operation. Although the pooled results showed a statistically significant reduction in blood loss of $8 \mathrm{ml}$ in the CNDL group, this difference is not clinically significant. In addition, the pooled results showed that patients receiving C-NDL presented improved postoperative pain and postoperative VAS scores ( $24 \mathrm{~h}$ after operation). In particular, groin pain was greatly improved. These results are consistent with those of Kim's study [45], which reported that SIMSs are superior with respect to immediate postoperative pain. The difference may be explained by the surgical procedure. Similar to other SIMSs, the $\mathrm{C}-\mathrm{NDL}$ is inserted through a single vaginal incision and blindly avoids the retropubic space and obturator foramen. The reduction in pain occurrence with C-NDL is related to the fact that there is no incision in the groin area, the sling does not reach the groin, and there is no foreign body sensation. The surgical routine also decreases the risk of blood vessel and nerve injury, consistent with our present analysis. In Baya's study, after three-year follow-up, there were no cases of groin pain, and only one patient had a mild haematoma [46]. In addition to the cure rate, postoperative pain also plays an important role in patient satisfaction. In a study by Schellart et al., patients with SUI were willing to accept 
a relatively lower cure rate with a less invasive procedure to avoid postoperative pain [47]. Although these outcomes from our study demonstrated that C-NDL slings cause less pain, some factors should be taken into consideration. Regarding the important outcome of groin pain, only three studies reported the outcome independently; some studies included it in the postoperative pain outcome. The postoperative VAS scores compared the feeling of postoperative pain, which may be influenced by incisions and individual differences. The different anaesthesia protocols among the studies may also contribute heterogeneity to the postoperative VAS results. In addition, the pain evaluation for this surgery is shortterm. Lv et al. reported no significant difference between the two groups in VAS at 6 months after surgery, which was associated with the postoperative time [26]. Further studies should pay more attention to groin pain and consider its relative influence. With respect to the length of hospital stay, a previous meta-analysis showed that SIMSs involve a shorter hospitalization time than transobturator slings [48]. However, our results showed no significant differences in hospital stay between the two groups. According to our clinical experience, the length of hospital stay might be associated with the patients' baseline basic characteristics and with hospital conditions, which are affected by human factors. However, after excluding the study by Fernandez et al., the difference was significant; that study included patients with POP, which may influence the results. In addition, the inpatient stay was fixed at 1 to 2 days, which also indicates that C-NDL slings involve a fast recovery time.

The results of the present meta-analysis, revealed no remarkable difference between the two types of slings with respect to vaginal tape erosion. Some SIMS, such as TVT-Secure and Mini-Arc, have been withdrawn from clinical use due to their nonideal efficacy and high risk of mesh exposure [49, 50]. The C-NDL sling is shorter than the standard sling and thus introduces, less foreign material. Due to the use of monofilament knotless weaving technology, the CNDL sling is macroporous, with a porosity of 55\%; thus, the risk of bacterial retention and reproduction resulting from the dead space caused by knotting after implantation in the human body is reduced [51, 52]. The C-NDL sling also contributes to the reduction in possible complications. In addition, the incidence of urinary retention, de novo urgency and/or worsening of pre-existing urgency, difficulty urinating, urinary tract infection, bladder injury, and haematoma were not significantly different between the groups. Some complications, such as vaginal tape erosion and urinary tract infection, will appear over time. Due to the limitations in follow-up time, long-term safety is still worth observing. Based on the simple operation required, the C-NDL procedure is more suitable for local anaesthesia [42]. Additionally, compared to the traditional sling, the mini-sling is considered lower cost [53, 54]. ElSheemy et al. reported they reduced the cost from US $\$ 500$ to US $\$ 10$ by using a surgeontailored ordinary polypropylene mesh through the needle-less single-incision technique [55]. More studies are required to verify the cost-effectiveness of the C-NDL procedure in the management of SUI.

There were several limitations to our study. First, the included RCTs did not describe the blinding procedures clearly and in detail, which might have led to conclusion bias. Some potential biases caused by CCTs are inevitable. Moreover, the heterogeneity among these trials was found to be high in terms of several parameters, including operative time, hospital stay, blood loss, and postoperative VAS. The heterogeneity in these parameters can be explained by the differences in outcome definitions, measurements, and standards, such as the time from incision to closure and the overall time spent in the operating room. Haemoglobin levels or gauze was used to estimate blood loss. In addition, the availability of technical equipment and surgical experience also play critical roles in evaluating the effectiveness of the two techniques and could not be assessed in the present review. Another limitation of this study is that some included studies included unselected populations (patients with POP and different severity of SUI), and some patients included in two studies $[17,27]$ may have come from the same group. Finally, the follow-up times in these included studies were different and not sufficiently long, and the sample sizes and numbers of included studies were small; thus, more high-quality RCTs with long follow-up times are needed to further evaluate the effectiveness and safety of C-NDL. The results of this meta-analysis should be interpreted with caution due to these limitations.

\section{Conclusion}

In summary, C-NDL slings have similar short-term efficacy as TOT/TVT-O slings in curing pure SUI patients without evidence of ISD. Compared with TOT/TVT-O, C-NDL is associated with a shorter operative time (by 7 $\mathrm{min}$ ) and less blood loss (by $8 \mathrm{ml}$ ). In addition, C-NDL is associated with lower postoperative pain compared to TOT/TVT-O. The limitations identified should be taken into consideration when interpreting these results. Further large-volume, well-designed prospective RCTs with extensive follow-up are required to confirm long-term efficacy and safety.

Acknowledgements

Not applicable. 


\section{Authors' contributions}

ZL, BJ made contributions to conception and design of acquisition of data. $H Z, H L$ have been involved in revising it critically. ZL, BJ, SL, GZ analysed and interpreted the patient data. ZL, BJ performed the data analyses and wrote the manuscript. GZ helped perform the analysis with constructive discussions. HZ, HL contributed analysis tools. The authors read and approved the final manuscript

\section{Authors' information}

Zhenkai Luo and Binbin Jiao are first author.

\section{Funding}

None.

\section{Availability of data and materials}

The datasets used and/or analysed during the current study available from the corresponding author on reasonable request.

\section{Ethics approval and consent to participate} Not applicable.

\section{Consent for publication}

Not applicable.

\section{Competing interests}

The authors declare that they have no competing interests.

\section{Author details}

'Peking University China-Japan Friendship School of Clinical Medicine, Beijing, China. ${ }^{2}$ Department of Urology, China-Japan Friendship Hospital, Yinghuadong Road, Beijing 100029, Chaoyang District, China. ${ }^{3}$ Graduate School of Peking Union Medical College, China-Japan Friendship Institute of Clinical Medicine, Beijing, China. ${ }^{4}$ Graduate School of Peking Union Medical College and Chinese Academy of Medical Sciences, Beijing, China. ${ }^{5}$ Department of Urology, Beijing Hospital, National Center of Gerontology, Beijing, China.

\section{Received: 19 October 2019 Accepted: 27 April 2020}

Published online: 06 May 2020

\section{References}

1. Nambiar A, Cody JD, Jeffery ST, Aluko P. Single-incision sling operations for urinary incontinence in women. Cochrane Database Syst Rev. 2017;7: CD008709.

2. Donkelaar CST, Rosier PFWM, Kort LMOD. 990 international continence society definition of detrusor underactivity; analysis of clinical parameters and comparison with contractility grading methods. J Urol. 2016;195(4): e975.

3. Pizzoferrato AC, Fauconnier A, Fritel X, Bader G, Dompeyre P. Urethral closure pressure at stress: a predictive measure for the diagnosis and severity of urinary incontinence in women. Int Neurourol J. 2017;21(2):121-7.

4. DeLancey JO, Trowbridge ER, Miller JM, et al. Stress urinary incontinence: relative importance of urethral support and urethral closure pressure. J Urol. 2008;179(6):2286-90 discussion 2290.

5. Hay-Smith J, Herderschee R, Dumoulin C, Herbison P. Comparisons of approaches to pelvic floor muscle training for urinary incontinence in women: an abridged Cochrane systematic review. Eur J Phys Rehabil Med. 2012;48(4):689-705.

6. Lucas MG, Bosch RJ, Burkhard FC, et al. EAU guidelines on surgical treatment of urinary incontinence. Eur Urol. 2012;62(6):1118-29.

7. Park KK, Kim SD, Huh JS, Kim YJ. A study of clinical predictors associated with intrinsic sphincter deficiency in women with stress urinary incontinence. Int Neurourol J. 2017;21(2):139-42.

8. Deffieux X, Donnadieu AC, Porcher R, Gervaise A, Frydman R, Fernandez H. Long-term results of tension-free vaginal tape for female urinary incontinence: follow up over 6 years. Int J Urol. 2007:14(6):521-6.

9. Magon N, Kalra B, Malik S, Chauhan M. Stress urinary incontinence: what, when, why, and then what. J Midlife Health. 2011:2(2):57-64.

10. DeLancey JO. Structural support of the urethra as it relates to stress urinary incontinence: the hammock hypothesis. Am J Obstet Gynecol. 1994;170(6): 1713-20 discussion 1720-3
11. Palos CC, Maturana AP, Ghersel FR, Fernandes CE, Oliveira E. Prospective and randomized clinical trial comparing transobturator versus retropubic sling in terms of efficacy and safety. Int Urogynecol J. 2018;29(1):29-35.

12. Tammaa A, Aigmüller $T$, Hanzal $E$, et al. Retropubic versus transobturator tension-free vaginal tape (TVT vs TVT-O): five-year results of the Austrian randomized trial. NeurourolUrodyn. 2018;37(1):331-8.

13. Celada P, Cañete P, Ortiz Murillo E, Tarín JJ, Cano A. Effectiveness and quality of life 10 years after transobturator suburethral tape surgery for stress urinary incontinence. J Obstet Gynaecol Res. 2018:44(3):518-23.

14. Bozkurt M, Yumru AE, Salman S. Assessment of perioperative, early, and late postoperative complications of the inside-out transobturator tape procedure in the treatment of stress urinary incontinence. Clin Exp Obstet Gynecol. 2015;42(1):82-9.

15. Abdel-Fattah M, Ford JA, Lim CP, Madhuvrata P. Single-incision mini-slings versus standard midurethral slings in surgical management of female stress urinary incontinence: a meta-analysis of effectiveness and complications. Eu Urol. 2011:60(3):468-80.

16. Karateke A, Cam C, Ince SB, et al. Effects of single vaginal incision technique on quality of life in women with stress urinary incontinence. J Minim Invasive Gynecol. 2011;18(5):634-9.

17. Martinez Franco $E$, Amat TL. Contasure-needleless ${ }^{\oplus}$ single incision sling compared with transobturator TVT-O ${ }^{\oplus}$ for the treatment of stress urinary incontinence: long-term results. Int Urogynecol J. 2015;26(2):213-8.

18. Mostafa A, Agur W, Abdel-All M, et al. Oxford Centre for Evidence based medicine-levels of evidence; 2009. Available from: http://www.cebm.net/ oxford-centre-evidence-based-medicine levels-evidencemarch-2009/. Accessed 24 May 2016.

19. Clark HD, Wells GA, Huët $C$, et al. Assessing the quality of randomized trials: reliability of the Jadad scale. Control Clin Trials. 1999;20(5):448-52.

20. Wells GA, Shea B, O'Connell, et al. The Newcastle Ottawa scale (NOS) for assessing the quality of nonrandomized studies in meta analyses: Ottawa Hospital Research Institute. http://www.ohri.ca/programs/clinical epidemiolog y/oxford.asp. Accessed 24 May 2016.

21. Luo D, Wan X, Liu J, Tong T. Optimally estimating the sample mean from the sample size, median, mid-range, and/or mid-quartile range. Stat Methods Med Res. 2018:27(6):1785-805.

22. Wan X, Wang W, Liu J, Tong T. Estimating the sample mean and standard deviation from the sample size, median, range and/or interquartile range. BMC Med Res Methodol. 2014;14:135.

23. Dogan O, Kaya AE, Pulatoglu C, Basbug A, Yassa M. A randomized comparison of a single-incision needleless (Contasure-needleless ${ }^{\circledR}$ ) minisling versus an inside-out transobturator (Contasure-KIM ${ }^{\circledast}$ ) mid-urethral sling in women with stress urinary incontinence: 24 -month follow-up results. Int Urogynecol J. 2018;29(9):1387-95.

24. Fernandez-Gonzalez S, Martinez Franco E, Lin Miao X, Amat TL. Contasureneedleless $s^{\circledast}$ compared with Monarc $^{\oplus}$ for the treatment of stress urinary incontinence. Int Urogynecol J. 2017:28(7):1077-84.

25. Gaber ME, Borg T, Samour H, Nawara M, Reda A. Two new mini-slings compared with transobturator tension-free vaginal tape for treatment of stress urinary incontinence: a 1-year follow-up randomized controlled trial. J Obstet Gynaecol Res. 2016:42(12):1773-81.

26. Fu Q, LV J, Fang W, et al. The clinical efficacy of needleless sling technique and tot in the treatment of female stress urinary incontinence: a prospective randomized controlled trial. Int J Clin Exp Med. 2017;10(4):7084.

27. Amat I, Tardiu L, Martínez Franco E, Laillla Vicens JM. Contasure-needleless compared with transobturator-TVT for the treatment of stress urinary incontinence. Int Urogynecol J. 2011;22(7):827-33.

28. Xu Q, Xu J, Zhuang $X$, et al. Effectiveness evaluation of Contasure needleless ${ }^{\circledR}$ needleless used in female patients with stress urinary incontinence. Chin J Gen Pract. 2017:15(12):2102-5.

29. Lucas MG, Bosch RJ, Burkhard FC, et al. EAU guidelines on surgical treatment of urinary incontinence. Actas Urol Esp. 2013;37(8):459-72.

30. Ulmsten U, Petros P. Intravaginal slingplasty (IVS): an ambulatory surgical procedure for treatment of female urinary incontinence. Scand J Urol Nephrol. 1995;29(1):75-82.

31. Novara G, Artibani W, Barber MD, et al. Updated systematic review and meta-analysis of the comparative data on colposuspensions, pubovaginal slings, and midurethral tapes in the surgical treatment of female stress urinary incontinence. Eur Urol. 2010;58(2):218-38.

32. Daneshgari F, Kong W. Swartz M. Complications of mid urethral slings: important outcomes for future clinical trials. J Urol. 2008;180(5):1890-7. 
33. Delorme E. Transobturator urethral suspension: mini-invasive procedure in the treatment of stress urinary incontinence in women. Prog Urol. 2001; 11(6):1306-13.

34. de Leval J. Novel surgical technique for the treatment of female stress urinary incontinence: transobturator vaginal tape inside-out. Eur Urol. 2003; 44(6):724-30.

35. Dwyer PL, Karmakar D. Surgical management of urinary stress incontinence - where are we now. Best Pract Res Clin Obstet Gynaecol. 2019:54:31-40.

36. Huang ZM, Xiao H, Ji ZG, Yan WG, Zhang YS. TVT versus TOT in the treatment of female stress urinary incontinence: a systematic review and meta-analysis. Ther Clin Risk Manag. 2018;14:2293-303.

37. Burkhard F. C, Bosch J.L.H.R, Cruz F, et al. EAU Guidelines: Urinary Incontinence. EAU Guidelines Office https://uroweb.org/guideline/urinaryincontinence/\#4. Accessed 16 Feb 2020

38. Meschia M, Bertozzi R, Pifarotti $P$, et al. Peri-operative morbidity and early results of a randomised trial comparing TVT and TVT-O. Int Urogynecol J Pelvic Floor Dysfunct. 2007;18(11):1257-61

39. Collinet $\mathrm{P}$, Ciofu $\mathrm{C}$, Costa $\mathrm{P}$, et al. The safety of the inside-out transobturator approach for transvaginal tape (TVT-O) treatment in stress urinary incontinence: French registry data on 984 women. Int Urogynecol J Pelvic Floor Dysfunct. 2008;19(5):711-5.

40. Zullo MA, Schiavi MC, Luffarelli P, Prata G, Di Pinto A, Oliva C. TVT-O vs. TVTAbbrevo for stress urinary incontinence treatment in women: a randomized trial. Int Urogynecol J. 2020;31(4):703-10

41. Shaw JS, Jeppson PC, Rardin CR. Decreasing transobturator sling groin pain without decreasing efficacy using TVT-Abbrevo. Int Urogynecol J. 2015;26(9): 1369-72.

42. Navazo R, Moreno J, Hidalgo C, et al. Contasure needleless: a single incision tot for the surgical treatment of stress urinary incontinence. Arch Esp Urol. 2009;62(9):719-23.

43. Kocjancic E, Sedlar A. A strength comparison of immediate and delayed extraction forces of five different single-incision slings anchor types: an animal model. Int Urogynecol J Pelvic Floor Dysfunct. 2012;23(2):S114.

44. van der Ploeg JM, van der Steen A, Oude Rengerink K, van der Vaart CH, Roovers JP. Prolapse surgery with or without stress incontinence surgery for pelvic organ prolapse: a systematic review and meta-analysis of randomised trials. BJOG. 2014;121(5):537-47.

45. Kim A, Kim MS, Park YJ, et al. Clinical outcome of single-incision slings, excluding TVT-Secur, vs standard slings in the surgical management of stress incontinence: an updated systematic review and meta-analysis. BJU Int. 2019;123(4):566-84

46. Baya G, Janin P. Surgical treatment of stress urinary incontinence in women with a single incision tot technique. Three years follow up. Int Urogynecol J Pelvic Floor Dysfunct. 2011;22:S1005.

47. Schellart RP, Casteleijn FM, Dijkgraaf M, Tutolo M, Roovers J. Are patients willing to trade cure rate against less pain? Patients' preferences for single incision midurethral sling or transobturator standard midurethral sling. NeurourolUrodyn. 2017;36(4):1187-93.

48. Jiao B, Lai S, Xu X, Zhang M, Diao T, Zhang G. A systematic review and meta-analysis of single-incision mini-slings (MiniArc) versus transobturator mid-urethral slings in surgical management of female stress urinary incontinence. Medicine (Baltimore). 2018;97(14):e0283.

49. Cornu JN, Sèbe P, Peyrat L, Ciofu C, Cussenot O, Haab F. Midterm prospective evaluation of TVT-Secur reveals high failure rate. Eur Urol. 2010;58(1):157-61.

50. Schellart RP, Oude Rengerink K, Van der Aa F, et al. A randomized comparison of a single-incision midurethral sling and a transobturator midurethral sling in women with stress urinary incontinence: results of 12 mo follow-up. Eur Urol. 2014;66(6):1179-85.

51. Padilla-Fernández B, García-Cenador MB, Gómez-García A, et al. Results of the surgical correction of urinary stress incontinence according to the type of transobturator tape utilized. Arch Ital Urol Androl. 2013;85(3):149-53.

52. Sivalingam N, Teng YH, Chong XY, Low CH, Manocha SK, Intan Sabreena MS. Incidence of vaginal erosion with different synthetic materials for suburethral sling in the treatment of stress urinary incontinence: a systematic review. Med J Malaysia. 2018;73(3):147-53.

53. Boyers D, Kilonzo M, Mostafa A, Abdel-Fattah M. Comparison of an adjustable anchored single-incision mini-sling, Ajust $\left({ }^{(}\right)$, with a standard mid-urethral sling, TVT-O (TM) : a health economic evaluation. BJU Int. 2013; 112(8):1169-77.

54. Castañeda E, Sanz-Granda Á, Hidalgo A, Meza DF, Marqueta JM, Carreras M. Cost-effectiveness analysis of surgical Management of Stress Urinary
Incontinence with single-incision mini-sling versus tension-free vaginal obturator in Spain. Value Health. 2014;17(7):A509.

55. ElSheemy MS, Ghamrawy H, Fathy $\mathrm{H}$, et al. Use of surgeon-tailored polypropylene mesh as a needle-less single-incision sling for treating female stress urinary incontinence: preliminary results. Arab J Urol. 2015;13(3):191-8.

\section{Publisher's Note}

Springer Nature remains neutral with regard to jurisdictional claims in published maps and institutional affiliations.

\section{Ready to submit your research? Choose BMC and benefit from:}

- fast, convenient online submission

- thorough peer review by experienced researchers in your field

- rapid publication on acceptance

- support for research data, including large and complex data types

- gold Open Access which fosters wider collaboration and increased citations

- maximum visibility for your research: over $100 \mathrm{M}$ website views per year

At BMC, research is always in progress.

Learn more biomedcentral.com/submissions 